plenty. This means raising the general standard of living and making the economic struggle for existence less intense and ruthless. The final aims are to induce the maximum of economic efficiency, economic equity and personal freedom. Raising wages and reducing costs are not general remedies. They must be supported by measures to stimulate investment and consumption, and Dr. Osborn stresses the value of more generous State provision for sickness, old age and child welfare, the endowment of research, public works, consumer subsidies and the encouragement of drama and the arts. Means to check inflation are essential as well as the control of land values, the share market and overseas influences. Economic self-sufficiency he considers is not necessarily retrograde, but he emphasizes the necessity of unorthodox methods and also of safeguards against bureaucracy in the economic planning required.

\section{The Forests of India}

Ir would perhaps be difficult to find stronger evidence of the changes which have taken place in the management of the forests of India and the almost complete manner in which the Secretary of State for India, and the Central Government of India itself, are dissociating themselves from their administration, than is provided by the Inspector-General of Forest's Quinquennial Review ending March 31, 1939. (Ann. Return of Statistics relating to Forest Administration in British India for 1938-39 and Quinquennia] Review ending March 31, 1939. Govt. of India Press, Calcutta, 1941.) For well over half a century the forests of India, their protection and improve. ment (and incidentally the increasing revenue they yielded), had formed a personal pre-occupation of successive Secretaries of State for India and (with that spur) of successive Governors-General and Viceroys. With increasing efficiency in management it became no longer possible for an inspector-general to portray in an annual report, kept within official requirements of space, the work being carried out throughout India and Burma. The latter was therefore reduced to tabular statements of statistics only, whilst a quinquennial report gave an eye-picture of the progress in management and the position of the forest estate.

It can now be realized that these reports have the very highest value in the light of the new position brought about by the Government of India Act, 1935, under which the forests are transferred to the individual provinces. The India Forest Service at present numbers 219 officers, of whom 163 were recruited at home direct to the Service. Gradually, with the retirement of these officers, the forests and their management will become purely the affair of the various provincial Governments. Even the senior administrative appointments, conservators and chief conservators in provinces, will no longer, it is said, be made by the Central Government. The Government of India still maintains an InspectorGeneral of Forests, shorn of all power, who is at the same time president of the Forest Research Institute and College at Dehra Dun. At the College the officers for the new 'Superior Forest Services' of the individual provinces are to be trained. The Inspector-General is permitted to visit, on invitation, the various provinces, but his reports on such visits are purely advisory. In fact, as the Quinquennial Report for 1934-35 to 1938-39 indicates, the chief position in forestry administration of the IrispectorGeneral at the present time is his occupancy of the presidentship of the Research Institute. Out of 24 pages in this report less than six are devoted to describing work of purely forest management, and the remainder to forestry research work. Yet this latter is dealt with very fully in the annual reports of the Research Institute.

The annual revenue from the great forest estate of India and Burma for the year 1936-37 (before the separation of the latter) amounted to Rs.4,38,07,019, or well over three million pounds sterling. In addition nearly half a million pounds sterling of forest produce is given away free or at reduced rates. Many senior men with long experience in the administration of this great forest estate, the correct management and maintenance of which is vital to India as a whole, view with concern and distrust the devolution of their powers and responsibility by the Secretary of State and Governor-General.

\section{An Index to Horticultural Research}

THE availability of research results of a purely horticultural character has been greatly increased by the publication of Horticultural Abstracts by the Imperial Bureau of Horticulture and Plantation Crops, East Malling, Kent. Mr. D. Akenhead, deputy director of the Bureau, has now compiled an index to the first ten volumes, covering the period 1931-40 (Sept. 1941, 160 pp., 25s.). The volume contains a subject index and an alphabetical list of authors ; it is world-wide in scope, and demonstrates the prosecution of an enormous volume of horticultural research during the decade it reviews. Greatest use of the index demands its relation to the journal which it serves, but the research worker can see from the present volume whether any work in his particular line has been reported. Detail is quite adequate for modern needs, for a reference can be found to apple sauce as well as to Rhizopus arrhizus rot of that crop, and to the utilization of waste potatoes, in addition to rubidium absorption in potato disks. The subject index is compiled with the different crop plants as the chief points of interest. The volume certainly achieves its expressed object of making information as available to the Englishspeaking horticultural worker as possible.

\section{Health of Palestine}

According to the report for 1939 recently published by the Department of Health in Palestine, the country was so much disturbed by political strife in that year as to prevent development of health work. The health of the people, however, was remarkably good, and there were no important epidemics. The recorded incidence of infectious diseases was the lowest for many years, and the death-rate from them half that of 1931. The total population numbered 1,501,698, of which 60 per cent were Moslems, 30 
per cent Jews and 10 per cent Christians and others. The birth-rate was twice as high among Moslems (46.4 per cent) as among the Jews $(23 \cdot 0$ per cent). Both rates were falling, but that of the Jews more rapidly than that of the Moslems. The death-rate of the Moslems was much more than double that of the Jews. Infantile mortality was $121 \cdot 5$ per 1,000 live births among the Moslems and 54 among the Jews; for Christians the rate was 101. These rates were the lowest ever recorded and showed a sharp decline from previous years. Of the various diseases diarrhœea caused 1,336 deaths and pneumonia 1,258, then in order of frequency came heart disease 617, cancer 364, corebral hæmorrhage 311, and nephritis 276. 3,394 cases of malaria were reported with 15 deaths, 1,235 cases of typhoid with 134 deaths, and 175 cases of paratyphoid with 2 deaths. There has been no increase in tuberculosis in the last ten years. Ophthalmias are a formidable problem.

\section{Piezo-Electro Crystal Filters}

A BRIEF outline of the history of the crystal filter has been published by J. E. B nson (A.W.A. Tech. Rev., 5, 191 ; 1941). The earliest application of piezo-electric crystals to frequency - selective circuits appears to have been made in 1920 by W. G. Cady, whose patent describes the behaviour of piezoelectric elements near resonance and their consequent use in the selection and measurement of high fre. quencies. L. Ezpenschied (Jan. 3, 1927) described the quartz-crystal band-pass filter having recurrent sections. This was followed by W. A. Marrison's patent (June 7, 1927) for a balanced crystal-gate filter designed for sharp response at a single frequency. In the same year, C. W. Hansell developed a similar bridge-balanced system, in which the parallel capacity of the crystal was balanced out of an equal capacity supplied from the input circuit in opposite phase to the crystal. Single-frequency rejection filters of the $T$-section type having a piezo-electric element in the shunt arm were described at about the same time by I. F. Byrnes. J. Robinson's stenode radiostat using a balanced crystal-filter circuit appeared in 1929 .

\section{Recent Earthquakes}

According to a radio message from Tokyo, the largest earthquake since 1930 shook southern Formosa on December 17. The epicentre is likely to have been near the town of Kagi around which most of the damage was done. Seventy-seven people were seriously injured and eighty-seven slightly hurt when 612 houses were destroyed and 918 badly damaged. Railway and telephone communications were temporarily severed. On the same day a violent earthquake occurred in the Mughla district of south-western Anatolia in Turkey. Damage was done to about eight hundred houses and a hospital, but only a few persons were injured. On December 20 an earthquake of moderate intensity shook Quetta. The shock lasted, according to human perception, for about ten seconds and was accompanied by a low rumbling sound. No damage has been reported, probably due to the new town having been built according to earthquake-proof design.

\section{Institute of Physics Planning Committee}

Tне Board of the Institute of Physics has appointed a planning committee with the following terms of reference: "To watch and to advise the Board on matters affecting Physics and Physicists, including their education and training, and on post-war planning." The constitution of the Committee, which has power to co-opt, is as follows: Sir Lawrence Bragg, Prof. J. A. Crowther, Mr. E: R. Davies, Dr. H. Lowery, Major C. E. S. Phillips, Dr. C. Sykes, Dr. F. C. Toy. At the request of the Board the Committee will proceed at once to consider certain matters concerning the education and training of physicists. Close contact will be maintained with the participating societies of the Institute, namely the British Institute of Radiology, the Faraday Society, the Physical Society, and the Royal Meteorological Society, as well as with other bodies concerned with the application of physics to industry.

\section{Announcements}

Prof. Henry Norris Russeld, research professor of astronomy at the University of Princeton, has been elected to an honorary fellowship at King's College, Cambridge. Prof. Russell, who is the doyen of American astronomers, graduated as Ph.D. at Princeton, after which he entered King's College, Cambridge, as an advanced student in 1902, and was in residence at Cambridge for three years. During that time he carried out research in collaboration with Mr. A. R. Hinks, now secretary of the Royal Geographical Society, upon parallax, and the methods they developed have become standard. This no doubt was a first step on the way to some of Prof. Russell's most notable work.

The Harrison Memorial Prize, which is awarded by a selection committee consisting of the presidents of the Chemical Society, the Institute of Chemistry, the Society of Chemical Industry and the Pharmaceutical Society, has been awarded for 1941 to Dr. Henry Norman Rydon. This prize is given to a chemist of either sex who is a natural-born British subject, not more than thirty years of age, who, in the opinion of the selection committee, shall during the previous five years have conducted the most meritorious and promising original investigations in chemistry. The Prize is to be regarded as an exceptional distinction to commemorate an exceptional man.

THe Town and Country Planning Association has arranged a series of fortnightly lunch-time meetings at 1.20 on "Post-War Reconstruction", beginning on January 8, at the Dome Lounge, Messrs. Dickins and Jones, 224 Regent Street, London, W.1. Admission is by ticket obtainable from the Association. The first meeting will be addressed by Mr. George Hicks, parliamentary secretary to the Ministry of Works and Buildings, who will discuss the part the Ministry can take in reconstruction.

REFerRING to the obituary notice of Mr. R. T. Baker in Nature of December 13, p. 718, Prof. John Read writes that Mr. Baker died at Cheltenham, New South Wales, on July 14, aged eighty-six years, 